\title{
Chemopreventive Effect of Allspice in Azoxymethane (AOM) Induced Fisher 344 Male Rats
}

\section{Ebube N. Onwasigwe, Martha Verghese*, Hadyn Reid, Carlissa Holden, Lillian Smith, Shantrell Willis, Rajitha Sunkara, Louis Shackelford, Lloyd T. Walker}

Nutritional Biochemistry and Carcinogenesis Laboratory, Department of Food and Animal Sciences, Alabama A and M University, Normal, AL, USA

Email: *martha.verghese@aamu.edu

How to cite this paper: Onwasigwe, E.N., Verghese, M., Reid, H., Holden, C., Smith, L., Willis, S., Sunkara, R., Shackelford, L. and Walker, L.T. (2019) Chemopreventive Effect of Allspice in Azoxymethane (AOM) Induced Fisher 344 Male Rats. Food and Nutrition Sciences, 10, 220-234.

https://doi.org/10.4236/fns.2019.102017

Received: November 22, 2017

Accepted: February 17, 2019

Published: February 20, 2019

Copyright ( $\odot 2019$ by author(s) and Scientific Research Publishing Inc. This work is licensed under the Creative Commons Attribution International License (CC BY 4.0).

http://creativecommons.org/licenses/by/4.0/

\begin{abstract}
Allspice contains phytochemicals which may have antioxidative and chemopreventive potential. The objective was to determine the effects of allspice on the AOM induced aberrant cryptic foci (ACF) in colon of Fisher 344 male rats. Rats were obtained from Harlan, IN, and raised in an environmentally controlled condition of 12 hours of light and dark cycles and at 50\% relative humidity. Rats in experimental groups were fed with different concentrations of allspice $(0.5 \%, 1 \%$ and $2 \%)$ in an AIN-93G based diet. Rats received AOM injections at 7 and 8 weeks of age at $16 \mathrm{mg} / \mathrm{kg}$ body weight. After 17 weeks, rats were asphyxiated with $\mathrm{CO}_{2}$, and liver, and colon samples were collected. Colons were stained with methylene blue to enumerate ACF and crypt multiplicity. Rats fed $0.5 \%$ allspice had the highest cecal $\mathrm{pH}$ (7.64) compared to control (6.88) $(P \leq 0.05)$. Rats in the treatment groups gained $225 \mathrm{~g}$ to $251 \mathrm{~g}$ over the 13-week period. A $29 \%$ reduction in total crypts was observed in rats fed $2 \%$ compared to $0.5 \%$ allspice. Highest number of crypts was seen in control group. Antioxidative enzyme activity was higher in rats fed allspice compared to the control group. Total tumors $(0.25-2.5)$, tumor bearing rat ratio $(1-2.5)$ and incidence rate $(50 \%-100 \%)$ in rats fed different concentrations of allspice were lower compared to rats in the control group $(6.6 \%, 5.8 \%$, and $100 \%$ respectively). Consumption of allspice in the diet reduced the number of ACF in Fisher 344 male rats. Allspice can be utilized in food formulations for its chemopreventive effects against colon cancer.
\end{abstract}

\section{Keywords}

ACF (Aberrant Crypt Foci), AOM-Azoxymethane, Methylene Blue,

Fisher 344 Male Rats, Crypt Multiplicity 


\section{Introduction}

Cancer is the uncontrolled growth of cells. It can be benign or malignant [1]. Benign tumors are localized in their tissue of origin and lack the ability to metastasize [2]. They resemble the cells in their primary location, while malignant cells grow uncontrollably and are at different stages of differentiation, and can metastasize to other parts of the body [3]. Carcinogenesis involves 3 steps; initiation, promotion and progression. Initiation is an irreversible process which involves genetic mutations of genes such as cell cycle arrest, tumor suppression, DNA damage repair genes etc. [4]. Promotion requires the presence of a tumor promoter which supports clonal expansion of abnormal cells [5]. During the progression stage, these abnormal cells continue to grow uncontrollably and start spreading to distant locations in the body, and this process is called metastasis [6]. Spices have shown possible chemo-preventive effect which can be due to the presence of phytochemicals in them [7]. Several processes are used to prevent the uncontrolled growth of cells such as neutralization or reduction of free radicals with the help of antioxidative enzymes, and increasing bone mineral content [8]. Antioxidative effect can be through induction of antioxidative enzymes, such as superoxide dismutase (SOD), catalase (CAT), glutathione, glutathione peroxidase (GPx) and glutathione-s-transferase (GST) assay [9]. Several studies have shown that phytochemicals such as ericifolin, gallic acid and flavonoids may play a role in prevention of cancer through some of these mechanisms [10] [11]. A study conducted by Shamaladevi et al. (2013) showed that ericifolin is the prevalent phytochemical found in allspice may have antiproliferative effect against prostate cancer cells. Colon cancer is the third most frequently diagnosed cancer, and the second leading cause of cancer death in men [11]. This cancer can be due to inherited genes such as mutated APC (adenomatous polyposis coli) gene or modifiable risk factors such as obesity, physical inactivity, smoking, excessive consumption of fats etc. [12]. Colon cancer originates as precancerous lesions that appear in the form of polyps, which can progress to colon cancer [13]. Chemicals such as azoxymethane (AOM) can induce colon cancer, and have been used in different in vivo studies [14]. AOM is a potent chemical compound that requires few injections to induce colon cancer, unlike its predecessor 1,2-dimethylhydrazine which requires higher doses over a longer period of time to induce colon cancer [15]. AOM is metabolized through several steps to methyldiazonium ion, which causes genetic alteration, which can lead to colon cancer [16]. An example is through DNA methylation which can lead inactivation of several signaling pathways such as K-ras, and inactivation of different genes such as APC/ $\beta$ catenin gene, $\operatorname{TGF} \beta$ (transforming growth factor beta) gene mutation which regulate growth and differentiation of cells [17]. The aim of this study was to investigate the anticarcinogenic effects of allspice on AOM induced colon cancer in Fisher 344 male rats.

\section{Materials and Methods}

Powdered allspice was obtained from Monterey Bay Spice Company, and Fisher 
344 male rats at 3 weeks of age with an average weight of 90 grams were obtained from Harlan, IN. They are known to be calmer and less likely to bite. The rats were divided into the short and long term study respectively, and each study group contained a treatment and a control group. In the short term study (17 weeks), the number of ACF was observed, while in the long term study, the number of tumors was observed. All rats were provided with a control diet for a week before they were divided into their respective groups. The treatment groups included 3 groups of rats fed $0.5 \%, 1 \%$ and $2 \%$ of allspice, while the control feed did not contain allspice. In the short term study, the control group had 5 rats, while the treatment groups were divided into 3 rats per group. In the long term study, the rats were divided into 6 per treatment group and 8 rats in the control group. The rats were housed in steel cages, with a minimum of 2 and a maximum of 3 rats per cage. Food and water was provided ad libitum. The environment was maintained at $25^{\circ} \mathrm{C}$ and $50 \%$ relative humidity. Rats were weighed every 2 weeks, total feed intake was calculated, and the food was made isocaloric after incorporation of allspice. All experiments were carried out implementing protocols approved by the Institutional Animal Care and Use Committee of Alabama A\&M University.

\subsection{Experimental Design}

Long and short term study lasted for 39 and 17 weeks respectively. Rats in both groups were fed a growth diet AIN-93G [18], however, rats in the long-term study group was switched to a maintenance diet after 20 weeks AIN-93M [18] (Table 1). Allspice was incorporated into feed at different concentrations of $0.5 \%, 1 \%$, and $2 \%$. The experimental design is shown below (Figure 1). Rats in the short term study contained 3 rats per group, and the long term study rats were divided into 6 rats per treatment group and in the control group.

Table 1. Allspice incorporated in AIN-93G food formulation.

\begin{tabular}{ccccc}
\hline INGREDIENT & $(\mathrm{g})$ & $(\mathrm{g})$ & $(\mathrm{g})$ & Control $(\mathrm{g})$ \\
\hline Cornstarch & 460.70 & 455.70 & 445.70 & 465.70 \\
Sucrose & 100 & 100 & 100 & 100 \\
Casein & 140 & 140 & 140 & 50 \\
Fiber & 50 & 50 & 50 & 40 \\
Soybean Oil & 40 & 40 & 40 & 155 \\
Dextrose & 155 & 155 & 155 & 35 \\
Mineral Mix & 35 & 35 & 35 & 10 \\
Vitamin Mix & 10 & 10 & 10 & 1.80 \\
L-Cysteine & 1.80 & 1.80 & 1.80 & 2.50 \\
Choline & 2.50 & 2.50 & 2.50 & 0 \\
Allspice & $(0.5 \%) 5$ & $(1 \%) 10$ & $(2 \%) 20$ & 1000 \\
Total & 1000 & 1000 & 1000 &
\end{tabular}




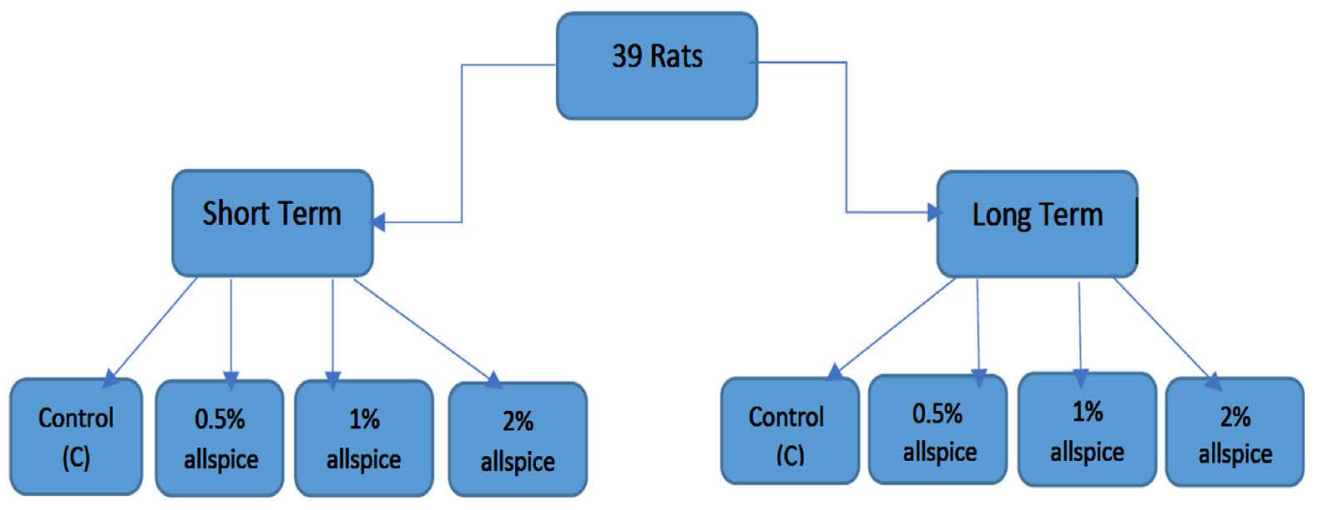

Figure 1. Animal study experimental design.

Azoxymethane (AOM)

AOM was obtained from Midwestern Research Institute, NCI Chemical Repository, Kansas City, Missouri. AOM was injected subcutaneously into all rats at $7^{\text {th }}$ and $8^{\text {th }}$ week at $24 \mathrm{mg} / \mathrm{kg}$ body weight. Control rats did not receive any AOM injections. At the end of the study, the short term rats were asphyxiated, while the long term rats were asphyxiated at the 39-week period. Tissue samples such as liver, bone (femur), liver, colon and cecal content were collected and analyzed. The cecal contents were collected, weighed and $\mathrm{pH}$ was determined. Liver samples were frozen in liquid nitrogen, homogenized in PBS and stored at appropriate temperature $\left(-80^{\circ} \mathrm{C}\right)$ for future use.

\subsection{Observation of ACF}

The colon was prepared by dividing into proximal and distal segments, followed by cutting into $2 \mathrm{~cm}$ segments and stained with $1 \%$ methylene blue; and observed under the microscope for enumeration of ACF and crypts.

\subsection{Tumor Characterization}

The presence and number of tumors were observed at the end of the long term animal study. The tumor incidence in both proximal and distal segments was analyzed. The presence of tumor was further analyzed based on the location, size, number and tumor per tumor bearing rat ratio (T/TBR).

\subsection{Bone Mineral Content}

The bone samples (femur) were collected and a sample mixture was prepared in HCL. An inductively coupled plasma analyzer was used to determine the bone mineral content (Calcium, Iron, Magnesium, Phosphorous, Zinc and potassium).

Antioxidant Enzyme Activity

Assays (SOD, CAT, GPx, GSH, GST) were carried out using liver samples to see if allspice had any significant effect on enzyme activity. All experiments were carried out in triplicates and results were expressed as means \pm standard error of mean (SEM). 


\subsection{Statistical Analysis}

Assays (Superoxide Dismutase (SOD), Catalase (CAT), Glutathione Peroxidase (GPx), Glutathione (GSH), Glutathione-S-Transferases (GST)) were carried out using liver samples to determine if allspice had any significant effect on enzyme activity or antioxidant status of rats using kits purchased from the Cayman Chemical Company (Ann Arbor, MI). All experiments were carried out in triplicates and results were expressed as means \pm standard error of mean (SEM).

\section{Results and Discussion}

The effect of feeding animals with different concentrations of allspice on weight gain, feed intake, and feed efficiency ratio (FER) was analyzed (Table 2).

Rats in the control group $(2.05 \mathrm{~g})$ had a significantly higher $(p \leq 0.05)$ weight gain and a lower feed intake compared to the treatment groups. Rats fed $1 \%$ of allspice had a higher weight gain among treatment groups, but this difference was not significant. The cecal weight was significantly $(p \leq 0.05)$ higher in rats fed $2 \%$ of allspice compared to the other treatment groups, but there was no significant difference with the control group (Table 3). Cecal $\mathrm{pH}$ was higher in rats fed $1 \%$ and $2 \%$ of allspice compared to the control group and those fed $0.5 \%$ of allspice. There was no significant difference in liver weight between the control and treatment groups.

The $\mathrm{pH}$, liver and cecal weight of rats fed different concentrations of allspice over a 39-week period are shown below (Table 4). There was no significant difference in the cecal weight in rats fed $1 \%$ of allspice and the control group. There was a higher cecal weight between control rats and those fed $0.5 \%$ and $2 \%$ of

Table 2. Weight gain, feed intake and FER in short term rats.

\begin{tabular}{ccc}
\hline Groups & Weight gain (g/day) & Feed Intake (g/day) \\
\hline Control & $2.05 \pm 0.04^{\mathrm{a}}$ & $16.74 \pm 0.5^{\mathrm{b}}$ \\
$0.5 \%$ Allspice & $1.10 \pm 0.28^{\mathrm{b}}$ & $18.55 \pm 2.23^{\mathrm{a}}$ \\
$1 \%$ Allspice & $1.61 \pm 0.43^{\mathrm{b}}$ & $18.62 \pm 1.91^{\mathrm{a}}$ \\
$2 \%$ Allspice & $1.04 \pm 0.52^{\mathrm{b}}$ & $19.11 \pm 1.48^{\mathrm{a}}$ \\
\hline
\end{tabular}

Values are expressed as means \pm SEM. Means in row with different superscripts $\left({ }^{\text {ab }}\right)$ are significantly $(p \leq$ 0.05 ) different using Tukey's Studentized range test, $\mathrm{n}=2$.

Table 3. Short term cecal weight, $\mathrm{pH}$, and liver weight in fisher 344 rats.

\begin{tabular}{cccc}
\hline Groups & Cecal Weight $(\mathrm{g})$ & Cecal pH & Liver Weight $(\mathrm{g})$ \\
\hline Control & $1.04 \pm 0.01^{\mathrm{a}}$ & $7.03 \pm 0.04^{\mathrm{b}}$ & $9.47 \pm 0.45^{\mathrm{b}}$ \\
$0.5 \%$ Allspice & $0.79 \pm 0.065^{\mathrm{b}}$ & $7.64 \pm 0.345^{\mathrm{a}}$ & $10.85 \pm 0.97^{\mathrm{b}}$ \\
$1 \%$ Allspice & $0.72 \pm 0.11^{\mathrm{b}}$ & $6.68 \pm 0.38^{\mathrm{b}}$ & $9.65 \pm 1.31^{\mathrm{b}}$ \\
$2 \%$ Allspice & $1.08 \pm 0.03^{\mathrm{a}}$ & $6.68 \pm 0.48^{\mathrm{b}}$ & $9.72 \pm 1.86^{\mathrm{b}}$ \\
\hline
\end{tabular}

Values are expressed as means \pm SEM. Means in with different superscripts $\left({ }^{\mathrm{ab}}\right)$ are significantly $(p \leq 0.05)$ different using Tukey's Studentized range test, $\mathrm{n}=2$. 
allspice. The cecal $\mathrm{pH}$ was significantly $(p \leq 0.05)$ lower in rats treated with allspice compared to the control group, except in the $1 \%$ group where the difference was not significant. Rats fed $2 \%$ allspice had a significantly $(p \leq 0.05)$ lower liver weight $(9.57 \mathrm{~g})$ compared to all other groups.

Total ACF was significantly higher $(p \leq 0.05)$ in the control group compared to the treatment groups (Table 5). Rats fed 2\% (20.5) of allspice had a lower ACF amount compared to rats fed $0.5 \%$ (42.5) and rats fed $1 \%$ (36) of allspice. The total crypts were higher in the control group (48) compared to the treatment groups. Rats fed $2 \%$ allspice (20) had the lowest total crypts compared to the other treatment groups.

Crypt multiplicity shows the number of crypts in one focus. The results show that rats fed $0.5 \%$ of allspice had the highest crypts with one focus (Figure 2). Rats in the control group had a higher number of 3 and 4 crypts per focus compared to the other groups. Rats fed $2 \%$ of allspice had fewer number of 5 or more crypts compared to the other groups.

Bone mineral content was analyzed using ICP after a 17 -week period, and the Table 4. Long term cecal weight, $\mathrm{pH}$, and liver weight in rats fed allspice.

\begin{tabular}{cccc}
\hline Groups & Final Cecal Weight $(\mathrm{g})$ & Cecal pH & Liver Weight $(\mathrm{g})$ \\
\hline Control & $1.06 \pm 0.04^{\mathrm{b}}$ & $7.48 \pm 0.03^{\mathrm{a}}$ & $11.63 \pm 1.00^{\mathrm{a}}$ \\
$0.5 \%$ Allspice & $1.35 \pm 0.17^{\mathrm{a}}$ & $7.37 \pm 0.07^{\mathrm{b}}$ & $10.41 \pm 0.87^{\mathrm{ab}}$ \\
$1 \%$ Allspice & $1.02 \pm 0.04^{\mathrm{b}}$ & $7.34 \pm 0.14^{\mathrm{ab}}$ & $12.22 \pm 0.89^{\mathrm{a}}$ \\
$2 \%$ Allspice & $1.15 \pm 0.08^{\mathrm{a}}$ & $6.90 \pm 0.13^{\mathrm{c}}$ & $9.57 \pm 0.65^{\mathrm{b}}$ \\
\hline
\end{tabular}

Values are expressed as means \pm SEM. ${ }^{\text {ab }}$ Means with different superscripts $\left.{ }^{\left({ }^{a b}\right.}\right)$ are significantly $(p \leq 0.05)$ different using Tukey's Studentized range test, $\mathrm{n}=4$.

Table 5. Aberrant crypt foci (ACF) and total crypts in rats fed with allspice.

\begin{tabular}{ccccc}
\hline Groups & ACF & Total Distal Crypts & Total Proximal Crypts & Total Crypts \\
\hline Control & $57.75 \pm 0.00^{\mathrm{a}}$ & $11 \pm 0.25^{\mathrm{a}}$ & $37 \pm 0.00^{\mathrm{a}}$ & $48 \pm 0.25^{\mathrm{a}}$ \\
$0.5 \%$ Allspice & $42.50 \pm 1.00^{\mathrm{c}}$ & $17 \pm 0.00^{\mathrm{b}}$ & $25 \pm 0.00^{\mathrm{b}}$ & $42 \pm 0.00^{\mathrm{b}}$ \\
$1 \%$ Allspice & $36.00 \pm 1.5^{\mathrm{b}}$ & $2 \pm 0.00^{\mathrm{c}}$ & $29 \pm 0.50^{\mathrm{c}}$ & $36 \pm 0.50^{\mathrm{c}}$ \\
$2 \%$ Allspice & $20.50 \pm 3.5^{\mathrm{d}}$ & $1 \pm 0.00^{\mathrm{d}}$ & $19.5 \pm 0.50^{\mathrm{d}}$ & $20 \pm 0.50^{\mathrm{d}}$ \\
\hline
\end{tabular}

Values are expressed as means \pm SEM. Means in row with different superscripts (abcd) are significantly ( $p \leq$ 0.05 ) different using Tukey's Studentized range test, $\mathrm{n}=2$.

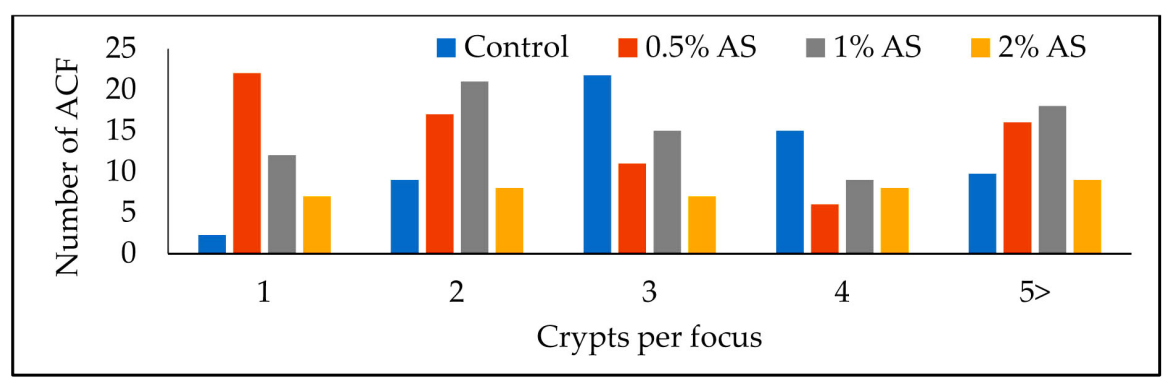

Figure 2. Crypt Multiplicity in Rats fed $0.5 \%, 1 \%$, and $2 \%$ allspice. 
results are shown below (Table 6). The bone Ca content was significantly lower in the control group $(128.38 \mu \mathrm{g} / \mathrm{g})$ compared to the treatment groups. The bone Ca content in the treatment groups increased with increasing concentration of allspice. All other mineral content showed a significant increase $(p \leq 0.05)$ between the control group and rats fed $2 \%$ of allspice.

In the long-term study, there was a significantly $(p \leq 0.05)$ higher bone $\mathrm{Ca}$ content in treatment rats compared to the control rats $(128.38 \mu \mathrm{g} / \mathrm{g})$, with rats fed $2 \%(299.7 \mu \mathrm{g} / \mathrm{g})$ of allspice having the highest bone Ca content (Table 7). There was no significant difference in bone $\mathrm{Fe}$ and $\mathrm{K}$ content in between the control and treatment group. $\mathrm{Mg}$ and $\mathrm{P}$ content in treatment groups were significantly higher $(p \leq 0.05)$ compared to the control group. Zn content was significantly higher in the treatment group compared to the control group (1.09). Rats fed $1 \%$ of allspice had a significantly $(p \leq 0.05)$ higher $\mathrm{Zn}$ content $(1.712$ $\mu \mathrm{g} / \mathrm{g}$ ) compared to rats in other treatment groups.

The effect of allspice on antioxidative enzymes in rats treated with different concentrations of allspice over a 17-week period is shown below (Table 8). Superoxide dismutase showed a significantly $(p \leq 0.05)$ higher SOD activity in the control group $(3.173 \mathrm{U} / \mathrm{ml})$ compared to the treatment groups. Catalase enzyme activity was significantly higher $(p \leq 0.05)$ in treatment groups compared to the control group. Glutathione activity was significantly higher $(p \leq 0.05)$ in the treatment groups (9.24 to $24.97 \mu \mathrm{M})$ compared to the control group $(0.3 \mu \mathrm{M})$. GPx activity was significantly higher $(\mathrm{p} \leq 0.05)$ in treatment groups $(268.69$ to $322.19 \mathrm{nmol} / \mathrm{min} / \mathrm{ml})$ compared to the control group $(1.42 \mathrm{nmol} / \mathrm{min} / \mathrm{ml})$. GST

Table 6. Bone minerals in rats fed allspice diets for 17 weeks.

\begin{tabular}{|c|c|c|c|c|c|c|c|}
\hline Groups & $\begin{array}{c}\mathrm{Ca} \\
\mu \mathrm{g} / \mathrm{g}\end{array}$ & $\begin{array}{c}\mathrm{Fe} \\
\mu \mathrm{g} / \mathrm{g}\end{array}$ & $\begin{array}{c}\mathrm{Mg} \\
\mu \mathrm{g} / \mathrm{g}\end{array}$ & $\begin{array}{c}\mathrm{Mn} \\
\mu \mathrm{g} / \mathrm{g}\end{array}$ & $\begin{array}{c}P \\
\mu \mathrm{g} / \mathrm{g}\end{array}$ & $\begin{array}{c}\mathrm{Zn} \\
\mu \mathrm{g} / \mathrm{g}\end{array}$ & $\begin{array}{c}\mathrm{K} \\
\mu \mathrm{g} / \mathrm{g}\end{array}$ \\
\hline Control & $128.38 \pm 8.66^{\mathrm{d}}$ & $0.44 \pm 0.02^{\mathrm{b}}$ & $12.00 \pm 0.63^{\mathrm{b}}$ & $0.005 \pm 0.00^{\mathrm{d}}$ & $369.42 \pm 30.46^{\mathrm{b}}$ & $1.0978 \pm 0.11^{\mathrm{b}}$ & $7.802 \pm 0.70^{\mathrm{b}}$ \\
\hline 0.5\% Allspice & $251.30 \pm 0.09^{c}$ & $0.41 \pm 0.02^{\mathrm{b}}$ & $12.98 \pm 1.04^{\mathrm{b}}$ & $0.004 \pm 0.00^{c}$ & $393.78 \pm 6.86^{\mathrm{b}}$ & $1.199 \pm 0.11^{\mathrm{b}}$ & $8.139 \pm 1.31^{\mathrm{b}}$ \\
\hline 1\% Allspice & $255.10 \pm 0.03^{b}$ & $0.57 \pm 0.06^{\mathrm{a}}$ & $15.05 \pm 1.40^{\mathrm{a}}$ & $0.006 \pm 0.00^{\mathrm{b}}$ & $468.37 \pm 35.69^{\mathrm{a}}$ & $1.423 \pm 0.21^{\mathrm{a}}$ & $9.31 \pm 0.74^{\mathrm{b}}$ \\
\hline $2 \%$ Allspice & $270.70 \pm 0.36^{\mathrm{a}}$ & $0.57 \pm 0.05^{\mathrm{a}}$ & $16.40 \pm 1.33^{\mathrm{a}}$ & $0.007 \pm 0.00^{\mathrm{a}}$ & $489.69 \pm 29.23^{\mathrm{a}}$ & $1.487 \pm 0.17^{\mathrm{a}}$ & $12.13 \pm 0.19^{\mathrm{a}}$ \\
\hline
\end{tabular}

$\mathrm{Ca}=$ Calcium, $\mathrm{Fe}=$ Iron, $\mathrm{Mg}=$ Magnesium, $\mathrm{Mn}=$ Manganese, $\mathrm{P}=$ Phosphorus, $\mathrm{Zn}=\mathrm{Zinc}, \mathrm{K}=$ Potassium. Values are expressed as means $\pm \mathrm{SEM}$. Means in row with different superscripts $\left({ }^{\mathrm{abcd}}\right)$ are significantly $(p \leq 0.05)$ different using Tukey's Studentized range test, $\mathrm{n}=6$.

Table 7. Effect of allspice on bone mineral content after 39 weeks.

\begin{tabular}{|c|c|c|c|c|c|c|c|}
\hline Groups & $\begin{array}{c}\mathrm{Ca} \\
\mu \mathrm{g} / \mathrm{g}\end{array}$ & $\begin{array}{c}\mathrm{Fe} \\
\mu \mathrm{g} / \mathrm{g}\end{array}$ & $\begin{array}{c}\mathrm{Mg} \\
\mu \mathrm{g} / \mathrm{g}\end{array}$ & $\begin{array}{c}\mathrm{Mn} \\
\mu \mathrm{g} / \mathrm{g}\end{array}$ & $\begin{array}{c}P \\
\mu \mathrm{g} / \mathrm{g}\end{array}$ & $\begin{array}{c}\mathrm{Zn} \\
\mu \mathrm{g} / \mathrm{g}\end{array}$ & $\begin{array}{c}\mathrm{K} \\
\mu \mathrm{g} / \mathrm{g}\end{array}$ \\
\hline Control & $128.38 \pm 8.66^{c}$ & $0.441 \pm 0.017^{\mathrm{a}}$ & $12.00 \pm 0.633^{b}$ & $0.005 \pm 0.00^{\mathrm{b}}$ & $369.42 \pm 30.46^{\mathrm{b}}$ & $1.097 \pm 0.105^{c}$ & $7.802 \pm 0.703^{\mathrm{a}}$ \\
\hline 0.5\% Allspice & $247.8 \pm 15.40^{\mathrm{ab}}$ & $0.499 \pm 0.10^{\mathrm{a}}$ & $14.949 \pm 0.62^{\mathrm{a}}$ & $0.006 \pm 0.00^{\mathrm{a}}$ & $493.14 \pm 23.409^{\mathrm{a}}$ & $1.494 \pm 0.099^{\mathrm{b}}$ & $8.361 \pm 1.093^{\mathrm{a}}$ \\
\hline 1\% Allspice & $285.0 \pm 30.90^{\mathrm{ab}}$ & $0.492 \pm 0.0621^{\mathrm{a}}$ & $16.713 \pm 1.42^{\mathrm{a}}$ & $0.005 \pm 0.00^{\mathrm{b}}$ & $539.94 \pm 41.36^{\mathrm{a}}$ & $1.712 \pm 0.160^{\mathrm{a}}$ & $8.48 \pm 1.647^{\mathrm{a}}$ \\
\hline 2\% Allspice & $299.7 \pm 20.00^{\mathrm{a}}$ & $0.399 \pm 0.075^{\mathrm{a}}$ & $14.96 \pm 0.80^{\mathrm{a}}$ & $0.007 \pm 0.001^{\mathrm{a}}$ & $484.93 \pm 25.04^{\mathrm{a}}$ & $1.51 \pm 0.098^{\mathrm{b}}$ & $7.799 \pm 1.869^{\mathrm{a}}$ \\
\hline
\end{tabular}

$\mathrm{Ca}=$ Calcium, $\mathrm{Fe}=$ Iron, $\mathrm{Mg}=$ Magnesium, $\mathrm{Mn}=$ Manganese, $\mathrm{P}=$ Phosphorus, $\mathrm{Zn}=\mathrm{Zinc}, \mathrm{K}=$ Potassium. Values are expressed as means $\pm \mathrm{SEM}$. Means in rows with different superscripts $\left({ }^{\mathrm{abc}}\right)$ are significantly $(p \leq 0.05)$ different using Tukey's Studentized range test, $\mathrm{n}=4$. 
Table 8. Enzymatic activity in short term animals treated with allspice.

\begin{tabular}{cccccc}
\hline Group & $\begin{array}{c}\text { Superoxide } \\
\text { Dismutase } \\
(\mathrm{U} / \mathrm{ml})\end{array}$ & $\begin{array}{c}\text { Catalase } \\
(\mathrm{nmol} / \mathrm{min} / \mathrm{ml})\end{array}$ & $\begin{array}{c}\text { Glutathione } \\
(\mu \mathrm{M})\end{array}$ & $\begin{array}{c}\text { Glutathione } \\
\text { Peroxidase } \\
(\mathrm{nmol} / \mathrm{min} / \mathrm{ml})\end{array}$ & $\begin{array}{c}\text { Glutathione } \\
\text { S-Transferase } \\
\mu \mathrm{mol} / \mathrm{min} / \mathrm{ml}\end{array}$ \\
\hline Control & $3.17 \pm 0.50^{\mathrm{a}}$ & $0.93 \pm 0.21^{\mathrm{b}}$ & $0.30 \pm 0.01^{\mathrm{c}}$ & $1.42 \pm 0.14^{\mathrm{c}}$ & $8.55 \pm 1.27^{\mathrm{d}}$ \\
$0.5 \%$ Allspice & $0.30 \pm 0.03^{\mathrm{d}}$ & $4.02 \pm 0.07^{\mathrm{a}}$ & $13.82 \pm 2.17^{\mathrm{b}}$ & $268.69 \pm 15.62^{\mathrm{b}}$ & $26.54 \pm 8.11^{\mathrm{c}}$ \\
$1 \%$ Allspice & $0.49 \pm 0.01^{\mathrm{c}}$ & $3.14 \pm 0.92^{\mathrm{a}}$ & $9.24 \pm 5.34^{\mathrm{b}}$ & $277.29 \pm 32.76^{\mathrm{ab}}$ & $44.10 \pm 7.86^{\mathrm{b}}$ \\
$2 \%$ Allspice & $0.59 \pm 0.01^{\mathrm{b}}$ & $3.99 \pm 0.5^{\mathrm{a}}$ & $24.97 \pm 3.95^{\mathrm{a}}$ & $322.19 \pm 26.88^{\mathrm{a}}$ & $57.22 \pm 5.22^{\mathrm{a}}$ \\
\hline
\end{tabular}

Values are expressed as means \pm SEM. Means in rows with different superscripts $\left({ }^{\text {abcd }}\right)$ are significantly $(p \leq$ 0.05 ) different using Tukey's Studentized range test, $\mathrm{n}=2$.

Table 9. Enzymatic activity in short term animals treated with allspice.

\begin{tabular}{cccccc}
\hline Group & $\begin{array}{c}\text { Superoxide } \\
\text { Dismutase } \\
(\mathrm{U} / \mathrm{ml})\end{array}$ & $\begin{array}{c}\text { Catalase } \\
(\mathrm{nmol} / \mathrm{min} / \mathrm{ml})\end{array}$ & $\begin{array}{c}\text { Glutathione } \\
\text { Peroxidase } \\
(\mathrm{nmol} / \mathrm{min} / \mathrm{ml})\end{array}$ & $\begin{array}{c}\text { Glutathione } \\
\text { S-Transferase } \\
(\mu \mathrm{mol} / \mathrm{min} / \mathrm{ml})\end{array}$ & $\begin{array}{c}\text { Glutathione } \\
(\mu \mathrm{M})\end{array}$ \\
\hline Control & $0.026 \pm 0.00^{\mathrm{a}}$ & $1.66 \pm 0.14^{\mathrm{b}}$ & $12.53 \pm 0.85^{\mathrm{b}}$ & $3.58 \pm 1.53^{\mathrm{c}}$ & $2.1 \pm 0.58^{\mathrm{c}}$ \\
$0.5 \%$ Allspice & $0.004 \pm 0.00^{\mathrm{b}}$ & $27.2 \pm 5.20^{\mathrm{a}}$ & $225.5 \pm 19.61^{\mathrm{a}}$ & $13.8 \pm 5.26^{\mathrm{b}}$ & $15.26 \pm 0.62^{\mathrm{b}}$ \\
$1 \%$ Allspice & $0.01 \pm 0.00^{\mathrm{c}}$ & $28.6 \pm 0.92^{\mathrm{a}}$ & $223.7 \pm 12.39^{\mathrm{a}}$ & $9.2 \pm 4.47^{\mathrm{b}}$ & $14.28 \pm 0.50^{\mathrm{b}}$ \\
$2 \%$ Allspice & $0.009 \pm 0.00^{\mathrm{d}}$ & $30.1 \pm 2.76^{\mathrm{a}}$ & $251.4 \pm 15.95^{\mathrm{a}}$ & $24.96 \pm 3.54^{\mathrm{a}}$ & $32.47 \pm 0.21^{\mathrm{a}}$ \\
\hline
\end{tabular}

Values are expressed as means \pm SEM. Means with different superscripts $\left({ }^{\text {abcd }}\right)$ are significantly $(p \leq 0.05)$ different using Tukey's Studentized range test, $\mathrm{n}=4$.

activity was significantly higher $(p \leq 0.05)$ in the treatment groups (26.54 to $57.22 \mu \mathrm{mol} / \mathrm{min} / \mathrm{ml})$ compared to the control group $(8.55 \mu \mathrm{mol} / \mathrm{min} / \mathrm{ml})$. Catalase activity was significantly higher $(p \leq 0.05)$ in the treatment groups (3.99 to $4.02 \mathrm{nmol} / \mathrm{min} / \mathrm{ml})$ compared to the control group $(0.93 \mathrm{nmol} / \mathrm{min} / \mathrm{ml})$, while the SOD activity was significantly lower $(p \leq 0.05)$ in the treatment groups $(0.30$ to $0.59 \mathrm{U} / \mathrm{ml})$ compared to the control group $(3.17 \mathrm{U} / \mathrm{ml})$.

In the long-term study, SOD activity was significantly higher $(p \leq 0.05)$ in the control group $(0.026 \mathrm{U} / \mathrm{ml})$ compared to the treatment groups (Table 9). Rats fed $2 \%(30.1 \mathrm{nmol} / \mathrm{min} / \mathrm{ml})$ of allspice had a significantly higher catalase activity compared to all other groups. GPx activity was significantly higher in treatment group compared to the control group. GST and GSH activity were significantly higher in rats fed $2 \%$ of allspice compared to other treatment groups and control group.

The total tumors observed after treatment with allspice is shown below (Table 10). The results show that control rats had the highest number of tumors compared to rats in the treatment group. There was also a numerical decrease in the number of tumors with increasing concentration of allspice, with rats fed $2 \%$ of allspice having the lowest number of tumors in the colon. Distal sections of the colon had a higher number of tumors in all groups compared to the tumors observed in the proximal segments.

Tumor incident rate in rats fed different concentrations of allspice and control rats is shown below (Table 11). The results show that control rats had a $100 \%$ 
Table 10. Total tumors in Rats Fed Allspice at $0.5 \%, 1 \%$, and $2 \%$ Levels.

\begin{tabular}{cccc}
\hline Treatment & Proximal Tumors & Distal Tumors & Total \\
\hline Control & 2.2 & 3.60 & 6.6 \\
$0.5 \%$ Allspice & 0.75 & 1.75 & 2.5 \\
1\% Allspice & 0.25 & 1.25 & 1.5 \\
2\% Allspice & 0 & 0.5 & 0.25 \\
\hline $\mathrm{n}=4$. & & &
\end{tabular}

Table 11. Tumor incidence in rats fed allspice.

\begin{tabular}{ccccc}
\hline Treatment & N1/N2 & Proximal Incidence (\%) & Distal Incidence (\%) & Total Incidence (\%) \\
\hline Control & $4 / 4$ & 100 & 100 & 100.00 \\
$0.5 \%$ Allspice & $4 / 4$ & 75 & 100 & 100.00 \\
$1 \%$ Allspice & $4 / 4$ & 25 & 100 & 100.00 \\
$2 \%$ Allspice & $2 / 4$ & 0 & 50 & 50.00 \\
\hline
\end{tabular}

$\mathrm{n} 1 / \mathrm{n} 2$ refers to rats with tumors/number of rats in the group.

Table 12. Effects of allspice on tumor size and tumors/tumor-bearing ratio (T/TBR).

\begin{tabular}{|c|c|c|c|c|}
\hline Treatment & Distal Tumor Size (mm) & Proximal Tumor Size (mm) & Total Tumor Size (mm) & $\mathrm{T} / \mathrm{TBR}$ \\
\hline Control & 17.78 & 5.91 & 13.28 & 5.8 \\
\hline $0.5 \%$ Allspice & 4.57 & 1.66 & 3.7 & 2.5 \\
\hline 1\% Allspice & 2.2 & 1.00 & 2 & 1.5 \\
\hline $2 \%$ Allspice & 1.00 & 0.00 & 1.5 & 1 \\
\hline
\end{tabular}

incident rate in both proximal and distal sections of the colon. The incidence rate decreased in the proximal sections with increasing concentrations of allspice, but only rats fed $2 \%$ of allspice had a lower distal total incidence rate (50\%).

Rats fed $2 \%$ of allspice had the smallest size of tumors compared to the other treatment groups, while the control rats had the largest size (Table 12). T/TBR is the number of tumors in rats with tumors, and the results show that rats fed $2 \%$ of allspice had the lowest T/TBR (1) compared to other treatment groups, and control rats had the highest T/TBR (5.8).

SOD activity was significantly higher $(p \leq 0.05)$ in the control group $(0.026$ $\mathrm{U} / \mathrm{ml}$ ) compared to the treatment groups (Table 12). Rats fed 2\% (30.1 $\mathrm{nmol} / \mathrm{min} / \mathrm{ml}$ ) of allspice had a significantly higher catalase activity compared to all other groups. GPx activity was significantly higher in treatment group compared to the control group. GST and GSH activity were significantly higher in rats fed $2 \%$ of allspice compared to other treatment groups and control group.

\section{Discussion}

Fruits, vegetables and spices have been shown to contain phytochemicals which 
have beneficial effects in preventing chronic diseases such as cancer [19]. These phytochemicals can assist the body in preventing the development of cancer via various mechanisms including increasing activity of antioxidative enzymes, inhibiting the growth of pathogenic bacteria in the gut, increasing the $\mathrm{pH}$ content of the colon through fermentation of short chain fatty acids [20]. AOM can be used to induce the formation of ACF and eventually, colon cancer [21]. This study was conducted to evaluate the potential inhibitory effect of allspice on the rate of colon cancer development.

In animals treated over a 17 -week period, results showed that allspice had an effect on weight gain. Rats fed $2 \%$ of allspice had a significantly lower weight compared to other treatment groups. The concentration of allspice also affected the total feed intake, with rats fed $0.5 \%$ allspice having the highest feed intake compared to other treatment groups. Allspice consists of phytochemicals similar to those found in cinnamon, nutmeg, clove and ginger which made it very potent. This high potency might have affected the amount consumed at higher concentration [22]. Consumption of spices can increase peristaltic of food in the gut thereby decreasing the transit time [23]. This might be why there was a decrease in weight gained in rats consuming a higher concentration of allspice. Spices can increase activity of digestive enzymes such as lipase which can facilitate lipid absorption from the gastrointestinal tract [24]. Spices can also affect the cecal weight and $\mathrm{pH}$ [25]. In the colon, fermentation of fiber takes place converting them into short chain fatty acids (butyric, propionic and acetic acid) [26]. These acids can support the growth of beneficial bacteria, such as Bifidobacterium and inhibit the growth of pathogenic bacteria [27]. They can inhibit the conversion of primary bile acids to secondary bile acids which are potential carcinogens [27]. Previous studies have shown that a decrease in $\mathrm{pH}$ can inhibit the growth of pathogenic bacteria [28]. The decrease in $\mathrm{pH}$ may be due to the fermentation of dietary fiber into short chain fatty acids such as butyric, propionic and acetic acid, which prevents the growth of pathogenic bacteria since these bacteria require an optimum $\mathrm{pH}$ of 7 for growth [28]. This study showed that increasing concentration of allspice in animal diet resulted in a decrease in $\mathrm{pH}$, which might have decreased the incidence of colon cancer. A decrease in $\mathrm{pH}$ can induce apoptosis of abnormal cells and induce secretion of antioxidant enzymes [29].

Previous studies have shown that bone mineral content might have played a role in the risk of colon cancer [30]. Calcium has several functions that include prevention of bone weakness and colon cancer [31]. Ca can induce growth of epithelial cells to repair damaged cells, and can form complexes with fatty acid and bile acids, thereby preventing the development of cancer [31]. This study showed that increasing concentration of allspice may be responsible for the increase in bone Ca content in the 17 and 39-week study period, which might have played a role in decreasing risk of colon cancer. Spices can increase the bioavailability of nutrients thereby aiding in their digestion and absorption in the body [32]. Allspice resulted in increases in Fe, Mg, Mn, P, Zn, and $\mathrm{K}$ in rats fed $2 \%$ of 
allspice compared to other groups meaning that it may have played a role increasing bone mineral content. In the long term study, bone mineral contents of $\mathrm{P}, \mathrm{Zn}$ and $\mathrm{K}$ were higher in rats fed 1 and 2 of allspice compared to the other groups. This study shows that diets rich in spices may have played a role in increasing the mineral content of the bone [32].

$\mathrm{AOM}$ is used to increase the risk of colon cancer compared to untreated rats, and Fisher 344 male rats are best suited for the study of colon cancer [33]. The results showed that the concentration of allspice may have played a role in decreasing the overall ACF number. Rats fed $2 \%$ of allspice had the lowest ACF number compared to the other treatment groups, while rats in the control group had the highest number of ACF. Crypt multiplicity is used to determine the likelihood of tumor development from precancerous lesions [34]. Presence of 3 or more crypts per focus is more likely to develop into tumors compared to 1 or 2 crypts, and results show there is decreased risk of colon cancer in rats fed $2 \%$ of allspice compared to the control group (Figure 2). Continuous consumption of allspice may decrease the risk of development of 5 or more crypts per focus, thereby decreasing the risk of colon cancer. The increase in ACF, crypt multiplicity might be due to increased angiogenesis, proliferation and inflammatory effects which can increase risk of cancer development [34].

Over the long-term study period, the number of tumors observed decreased in rats in the treatment group compared to the control group. The higher number of ACF and size of tumor in the control group may be due to the ability of phytochemicals in allspice to inhibit the growth of tumors through their antiproliferative and antiangiogenic effect [35]. A higher concentration of allspice may decrease both the number and size of tumors compared to other groups [36]. Tumor incidence and T/TBR decreased in rats fed higher concentrations of allspice compared to rats fed lower concentrations of allspice. There was an $88 \%$ decrease in the T/TBR between rats fed $2 \%$ of allspice and the control rats. Incidence rate of tumors decreased in rats fed $2 \%$ of allspice compared to the other groups, which might be due to the anticarcinogenic effect of allspice. These changes in tumor size, number, incidence rate and T/TBR may also be due to the antioxidant, antiproliferative, antiangiogenic, and anti-inflammatory effect of phytochemicals found in allspice [36] [37]. A previous study conducted by Bennink and his colleagues (2002) showed similar antiproliferative, antiangiogenic and antioxidant effect of phytochemicals present in beans on colon cancer. These results showed a decrease risk of colon cancer with increasing consumption of beans by the animals [38].

The body has an innate ability to combat free radicals, and phytochemicals have been shown to activate some of these antioxidative pathways [39]. Some of the pathways include activation of antioxidant enzymes such as GST, GPx, SOD, CAT, and antioxidant GSH. These enzymes and compounds play a role in neutralizing free radicals by tagging them for elimination from the body, or converting them from their oxidized form to a reduced form [39]. The results of this 
study show that allspice may have played a role in activating these antioxidative enzymes. Results from the long and short term studies show an increase in GPx, CAT, GST activities and GSH levels in the treatment groups compared to the control group. This shows that phytochemicals such as eugenol, gallic acid and myricetin may have played a role in their activation [40]. Previous studies have shown ability of phytochemicals to induce antioxidative enzymes [41]. Gajula and his colleagues (2010) looked at the ability of phytochemicals present in basil on the activity of catalase. The animal feed was incorporated with basil and the result showed an increase in CAT activity [42]. There was a decrease in SOD activity at higher concentrations of allspice after both 17 and 39-week study period. This might be due to the ability of allspice to neutralize superoxide radicals, eliminating the need for SOD activation.

\section{Conclusion}

This study showed that allspice may have anti-carcinogenic effects against colon cancer. Different concentrations of allspice showed different effects with higher concentrations being more effective in preventing colon cancer. The results showed a decrease in the number of ACF, crypt multiplicity, tumor size, tumor number, T/TBR and tumor incidence in rats fed higher concentrations (2\%) of allspice compared to those fed lower concentrations of allspice $(0.5 \%$ and $1 \%)$. Allspice may also be responsible for increased bone mineral content and induction of antioxidative enzymes. Results show that increasing concentration of allspice resulted in increased activities of CAT, GST, GPx and GSH levels. Allspice may have similar chemopreventive effects in humans, and studies need to be conducted to see if the same results can be replicated in humans.

\section{Acknowledgements}

This study was supported by The Agricultural Experimental Research Station, Alabama A and M University, Normal, Alabama, 35,762.

\section{References}

[1] Anand, P., Kunnumakara, A.B., Sundaram, C., Harikumar, K.B., Tharakan, S.T., Lai, O.S., Sung, B. and Aggarwal, B.B. (2008) Cancer Is a Preventable Disease That Requires Major Lifestyle Changes. Pharmaceutical Research, 25, 2097-2116. https://doi.org/10.1007/s11095-008-9661-9

[2] Roukos, D.H. (2009) Genome-Wide Association Studies: How Predictable Is a Person's Cancer Risk? Expert Review of Anticancer Therapy, 9, 389-392. https://doi.org/10.1586/era.09.12

[3] Grade, M., Wolff, H.A., Gaedcke, J. and Ghadimi, B.M. (2012) The Molecular Basis of Chemoradiosensitivity in Rectal Cancer: Implications for Personalized Therapies. Langenbeck's Archives of Surgery, 397, 543-555. https://doi.org/10.1007/s00423-012-0929-5

[4] Balaguer, F., Link, A., Lozano, J.J., Cuatrecasas, M., Nagasaka, T., Boland, C.R. and Goel, A. (2010) Epigenetic Silencing of miR-137 Is an Early Event in Colorectal Carcinogenesis. Cancer Research, 70, 6609-6618. 
https://doi.org/10.1158/0008-5472.CAN-10-0622

[5] Knudson, A.G. (2001) Two Genetic Hits (More or Less) to Cancer. Nature Reviews. Cancer, 1, 157-162. https://doi.org/10.1038/35101031

[6] Nguyen, H., Loustaunau, C., Facista, A., Ramsey, L., Hassounah, N., Taylor, H., Krouse, R., Payne, C.M., Tsikitis, V.L., Goldschmid, S., Banerjee, B., Perinee, R.F. and Bernstein, C. (2010) Deficient Pms2, ERCC1, Ku86, CcOI in Field Defects during Progression to Colon Cancer. Journal of Visualized Experiments, 41, e1931. https://doi.org/10.3791/1931

[7] Rubin, H. (2011) Fields and Field Cancerization: The Preneoplastic Origins of Cancer. Bioessays, 33, 224-231. https://doi.org/10.1002/bies.201000067

[8] Tsai, T.H., Tsai, P.J. and Ho, S.C. (2005) Antioxidant and Anti-Inflammatory Activities of Several Commonly Used Spices. Journal of Food Science, 70, C93- C97. https://doi.org/10.1111/j.1365-2621.2005.tb09028.x

[9] Ezeonu, D.O. (2017) The in Vivo and in Vitro Antioxidant Effect of the Flavonoid-Rich Fraction of the Methanol Extract of Jatropha tanjorensis Leaves. Doctoral Dissertation, University of Nigeria, Nsukka.

[10] Nakatani, N. (2000) Phenolic Antioxidants from Herbs and Spices. Biofactors, 13, 141-146. https://doi.org/10.1002/biof.5520130123

[11] Shamaladevi, N., Lyn, D.A., Shaaban, K.A., Zhang, L., Villate, S., Rohr, J. and Lokeshwar, B.L. (2013) Ericifolin: A Novel Antitumor Compound from Allspice That Silences Androgen Receptor in Prostate Cancer. Carcinogenesis, 34, 1822-1832. https://doi.org/10.1093/carcin/bgt123

[12] World Health Organization, \& World Health Organization. Management of Substance Abuse Unit (2014) Global Status Report on Alcohol and Health. World Health Organization, Geneva.

[13] Deng, G., Kakar, S. and Kim, Y.S. (2011) MicroRNA-124a and MicroRNA-34b/c Is Frequently Methylated in All Histological Types of Colorectal Cancer and Polyps, and in the Adjacent Normal Mucosa. Oncology Letters, 2, 175-180. https://doi.org/10.3892/ol.2010.222

[14] Yang, C.S., Chung, J.Y., Yang, G.Y., Chhabra, S.K. and Lee, M.J. (2000) Tea and Tea Polyphenols in Cancer Prevention. The Journal of Nutrition, 130, 472S-478S. https://doi.org/10.1093/jn/130.2.472S

[15] Zheng, Y., Kramer, P.M., Lubet, R.A., Steele, V.E., Kelloff, G.J. and Pereira, M.A. (1999) Effect of Retinoids on AOM-Induced Colon Cancer in Rats: Modulation of Cell Proliferation, Apoptosis and Aberrant Crypt Foci. Carcinogenesis, 20, 255-260. https://doi.org/10.1093/carcin/20.2.255

[16] Reddy, B.S. (1998) Prevention of Colon Cancer by Pre- and Probiotics: Evidence from Laboratory Studies. The British Journal of Nutrition, 80, S219-S223.

[17] Takahashi, M., Fukuda, K., Sugimura, T. and Wakabayashi, K. (1998) $\beta$-Catenin Is Frequently Mutated and Demonstrates Altered Cellular Location in Azoxymethane-Induced Rat Colon Tumors. Cancer Research, 58, 42-46.

[18] Boateng, J., Verghese, M., Shackelford, L., Walker, L.T., Khatiwada, J., Ogutu, S., Henderson, F., et al. (2007) Selected Fruits Reduce Azoxymethane (AOM)-Induced Aberrant Crypt Foci (ACF) in Fisher 344 Male Rats. Food and Chemical Toxicolo$g y, 45,725-732$. https://doi.org/10.1016/j.fct.2006.10.019

[19] Smith-Warner, S.A., Spiegelman, D., Yaun, S.S., Albanes, D., Beeson, W.L., Van Den Brandt, P.A., Giovannucci, E., et al. (2003) Fruits, Vegetables and Lung Cancer: A Pooled Analysis of Cohort Studies. International Journal of Cancer, 107, 1001-1011. 
https://doi.org/10.1002/ijc.11490

[20] Reddy, B.S., Hirose, Y., Lubet, R., Steele, V., Kelloff, G., Paulson, S., Rao, C.V., et al. (2000) Chemoprevention of Colon Cancer by Specific Cyclooxygenase-2 Inhibitor, Celecoxib, Administered during Different Stages of Carcinogenesis. Cancer Research, 60, 293-297.

[21] Kawamori, T., Lubet, R., Steele, V.E., Kelloff, G.J., Kaskey, R.B., Rao, C.V. and Reddy, B.S. (1999) Chemopreventive Effect of Curcumin, a Naturally Occurring Anti-Inflammatory Agent, During the Promotion/Progression Stages of Colon Cancer. Cancer Research, 59, 597-601.

[22] Watkins, B.A., Li, Y., Allen, K.G., Hoffmann, W.E. and Seifert, M.F. (2000) Dietary Ratio of $(n-6) /(n-3)$ Polyunsaturated Fatty Acids Alters the Fatty Acid Composition of Bone Compartments and Biomarkers of Bone Formation in Rats. The Journal of nutrition, 130, 2274-2284. https://doi.org/10.1093/jn/130.9.2274

[23] Basnet, P. and Skalko-Basnet, N. (2011) Curcumin: An Anti-Inflammatory Molecule from a Curry Spice on the Path to Cancer Treatment. Molecules, 16, 4567-4598. https://doi.org/10.3390/molecules16064567

[24] Aggarwal, B.B. and Sung, B. (2009) Pharmacological Basis for the Role of Curcumin in Chronic Diseases: An Age-Old Spice with Modern Targets. Trends in Pharmacological Sciences, 30, 85-94. https://doi.org/10.1016/j.tips.2008.11.002

[25] Wynder, E.L. and Reddy, B.S. (1974) Metabolic Epidemiology of Colorectal Cancer. Cancer, 34, 801-806.

[26] Nalini, N., Sabitha, K., Viswanathan, P. and Menon, V.P. (1998) Influence of Spices on the Bacterial (Enzyme) Activity in Experimental Colon Cancer. Journal of Ethnopharmacology, 62, 15-24. https://doi.org/10.1016/S0378-8741(98)00007-5

[27] Kim, C.S., Park, W.H., Park, J.Y., Kang, J.H., Kim, M.O., Kawada, T., Yu, R., et al. (2004) Capsaicin, a Spicy Component of Hot Pepper, Induces Apoptosis by Activation of the Peroxisome Proliferator-Activated Receptor $\gamma$ in HT-29 Human Colon Cancer Cells. Journal of Medicinal Food, 7, 267-273.

https://doi.org/10.1089/jmf.2004.7.267

[28] Valko, M., Rhodes, C., Moncol, J., Izakovic, M.M. and Mazur, M. (2006) Free Radicals, Metals and Antioxidants in Oxidative Stress-Induced Cancer. Chemico-Biological Interactions, 160, 1-40. https://doi.org/10.1016/j.cbi.2005.12.009

[29] MatÉs, J.M., Pérez-Gómez, C. and De Castro, I.N. (1999) Antioxidant Enzymes and Human Diseases. Clinical Biochemistry, 32, 595-603. https://doi.org/10.1016/S0009-9120(99)00075-2

[30] Cauley, J.A., Robbins, J., Chen, Z., Cummings, S.R., Jackson, R.D., LaCroix, A.Z., Pettinger, M., et al. (2003) Effects of Estrogen plus Progestin on Risk of Fracture and Bone Mineral Density: The Women's Health Initiative Randomized Trial. $J A M A, 290,1729-1738$. https://doi.org/10.1001/jama.290.13.1729

[31] Bonithon-Kopp, C., Kronborg, O., Giacosa, A., Räth, U., Faivre, J. and European Cancer Prevention Organisation Study Group (2000) Calcium and Fibre Supplementation in Prevention of Colorectal Adenoma Recurrence: A Randomised Intervention Trial. The Lancet, 356, 1300-1306. https://doi.org/10.1016/S0140-6736(00)02813-0

[32] Lappe, J.M., Travers-Gustafson, D., Davies, K.M., Recker, R.R. and Heaney, R.P. (2007) Vitamin D and Calcium Supplementation Reduces Cancer Risk: Results of a Randomized Trial. The American Journal of Clinical Nutrition, 85, 1586-1591. https://doi.org/10.1093/ajcn/85.6.1586

[33] Bird, R.P. and Good, C.K. (2000) The Significance of Aberrant Crypt Foci in Un- 
derstanding the Pathogenesis of Colon Cancer. Toxicology Letters, 112, 395-402. https://doi.org/10.1016/S0378-4274(99)00261-1

[34] Paulsen, J.E., Steffensen, I.L., Løberg, E.M., Husøy, T., Namork, E. and Alexander, J. (2001) Qualitative and Quantitative Relationship between Dysplastic Aberrant Crypt Foci and Tumorigenesis in the Min/+ Mouse Colon. Cancer Research, 61, 5010-5015.

[35] Dinkova-Kostova, A.T. and Talalay, P. (2008) Direct and Indirect Antioxidant Properties of Inducers of Cytoprotective Proteins. Molecular Nutrition \& Food Research, 52, S128-S138. https://doi.org/10.1002/mnfr.200700195

[36] Shishodia, S., Sethi, G. and Aggarwal, B.B. (2005) Curcumin: Getting Back to the Roots. Annals of the New York Academy of Sciences, 1056, 206-217.

https://doi.org/10.1196/annals.1352.010

[37] Mosley, C.A., Liotta, D.C. and Snyder, J.P. (2007) Highly Active Anticancer Curcumin Analogues. In: Aggarwal, B.B., Surh, Y.J. and Shishodia, S., Eds., The Molecular Targets and Therapeutic Uses of Curcumin in Health and Disease, Springer, US, 77-103. https://doi.org/10.1007/978-0-387-46401-5_2

[38] Bennink, M.R. (2002) Consumption of Black Beans and Navy Beans (Phaseolus vulgaris) Reduced Azoxymethane-Induced Colon Cancer in Rats. Nutrition and Cancer, 44, 60-65. https://doi.org/10.1207/S15327914NC441_8

[39] Surh, Y.J. (2003) Cancer Chemoprevention with Dietary Phytochemicals. Nature Reviews. Cancer, 3, 768. https://doi.org/10.1038/nrc1189

[40] Breinholt, V., Lauridsen, S.T., Daneshvar, B. and Jakobsen, J. (2000) Dose-Response Effects of Lycopene on Selected Drug-Metabolizing and Antioxidant Enzymes in the Rat. Cancer Letters, 154, 201-210. https://doi.org/10.1016/S0304-3835(00)00401-8

[41] Surh, Y.J. (2003) Cancer Chemoprevention with Dietary Phytochemicals. Nature Reviews. Cancer, 3, 768. https://doi.org/10.1038/nrc1189

[42] Gajula, D., Verghese, M., Boateng, I., Shackelford, L. and Mentreddy, S.R. (2010) Basil (Ocimum basilicum and Ocimum tenuiflorum) Reduces Azoxymethane Induced Colon Tumors in Fisher 344 Male Rats. Research Journal of Phytochemistry, 4, 136-145. https://doi.org/10.3923/rjphyto.2010.136.145 